\title{
Impact of Illicit Financial Flow on Economic Growth and Development: Evidence from Nigeria
}

\author{
${ }^{1}$ Amah Kalu Ogbonnaya, ${ }^{2}$ Okezie Stella Ogechuckwu \\ 1,2 Department of Accounting Michael Okpara University of Agriculture, Umudike
}

\begin{abstract}
This paper assessed the impact of illicit financial flow on economic growth and development in Nigeria. Data was sourced from the statistical bulletin of the Central bank of Nigeria and Global Financial Integrity estimates of illicit financial flows. Time series data from 1980-2015 was used. The variables were tested for unit root and co-integration and were found to have a long run relationship. The results further indicated that illicit financial flows had a significant impact both on economic growth and development. The study among others recommends that government of Nigeria and indeed other African countries must lobby developed nations to adopt control so that individuals who move funds out of Nigeria into tax havens and secrecy jurisdictions can be exposed. It was also recommended that African states and indeed Nigeria, in particular, must develop customs capacity in order to fight the massive outflows of capital through illicit practices.
\end{abstract}

Keywords: Illicit financial flows, Economic Growth, Globalization, Cross-Border

\section{Introduction}

Since the debt crisis in the early 1980s, attention has been focused on the outflow of capital resulting from distortionary domestic policies and political instability mainly in the developing nations. The rate at which huge sums of money are transferred out of developing countries illegally has become quite alarming. Consequently, cross-border illicit financial flows (Hereafter called IFFs) which serve to conceal illegal activities are no new phenomenon. With the growing globalisation of financial markets, the economic and political significance of these illegal activities has grown (GFI, 2013).

The issue of illicit financial flows ranks top on the international agenda, affecting both industrialized and developing countries. Though, the current scale of IFFs originating in developing countries cannot be measured. Precisely, it is believed that the value has been worth more than official development assistance from Organization for Economic Cooperation and Development (OECD) donor countries according to Global financial integrity report. These practices occur in all countries and are quite damaging both to the social and economic life of the nations and much more severe to the developing countries whose resources are small. Consequently, the issue of IFFs occupies a prominent place in development policy discourse of nations calling for a higher quality of national regulations, proper implementation and compliance with international best practices.

The concept of illicit financial flows is perceived by some as being vague and imprecise and its content controversial. As noted by the UNECA, it is "marred by a lack of terminological clarity, which somewhat limits the emergence of effective policy options". Illicit financial flows have been defined in different ways. It is the cross-border movement of money that is illegally 
obtained, transferred, or used. In an OECD (2010) report, IFFs is explained to mean crossborder capital transactions that either conceal illegal activities or facilitate them. Illicit financial flows are essentially generated by methods, practices and/or crimes aiming to transfer financial capital out of a country in contravention of national or international laws. In practice, illicit financial flows can be as simple as a transfer from a private account abroad evading taxes in complex schemes involving criminal networks that hide ownership.

Council for International Development (2014) defined illicit financial flows as the transfer of illegally earned assets or the hiding of legally earned assets to facilitate illegal tax evasion. Global Financial Integrity (2013) says IFFs are activities that involve the transfer of money collected through corruption, bribery, tax evasion, criminal activities and transactions involving contraband goods. Kar and Freltas (2012) opine that IFFs are funds that are illegally earned, transferred or utilised, and cover all unrecorded private financial assets by a resident in contravention of applicable laws and regulatory frameworks. In Baker's (2005) view, illicit financial flows are termed as 'dirty money' where dirty money is any money illegally earned, transferred or utilised. He argues that if it breaks any law in its origin, movement or use, then it is dirty money. In a seminar contribution to the dirty money literature, Reutter and Truman (2004) do not define dirty money explicitly instead they say it is the conversion of criminal income into assets that cannot be traced back to its underlying crime.

\subsection{Problem Statement}

Existing literature suggests that illicit financial flows involve the following practices: money laundering, bribery by international companies, tax evasion and trade mispricing. Whichever the case, illicit financial flows robs developing countries of resources that could be used to finance essential public services ranging from security and justice to basic social services such as health and education thus weakening their financial systems and economic potential. "The impact of this is indeed staggering especially for Africa and Nigeria in particular as it drains foreign reserves, heightens inflation, reduces tax collection, cancels investment and undermines free trade", - says Saheed and Ayodeji (2012) quoting GFI, 2010. Besides removing resources that could otherwise be used for poverty alleviation and economic growth, it tends to restrict the capacity and ability of affected countries to mobilize domestic resources and access foreign capital necessary to finance economic growth and development. Consequently, IFFs contributes to the retardation of economic growth and development of developing countries (Saheed and Ayodeji, 2012).

\subsection{Aim of the Study}

The issues raised above makes pertinent this study. Hence, the work seeks to assess the impact of illicit financial flows on Nigeria's economic growth and development. Specifically, the paper will assess:

1. The impact of illicit financial flows on economic growth in Nigeria

2. The impact of illicit financial flows on per capita income in Nigeria

To achieve the above objectives, two Research questions are raised

1. To what extent is Nigeria's economic growth affected by Illicit financial flows?

2. How does Illicit financial flow impact per capita income of Nigerians?

In achieving the Objectives of the study and providing answers to the research question, the following hypotheses will be tested:

1. HO: There is no significant impact of illicit financial flow on economic growth in Nigeria.

2. HO: There is no significant impact of illicit financial flow on per capita income of Nigerians.

The paper has five sections. Section I is introduction followed by section II, focusing on literature review. Section III is the methodology of the study, section IV summarizes the 
findings and discussions while section $\mathrm{V}$ draws some conclusions and offers some policy recommendations.

\section{Literature Review}

Illicit financial flows take many forms and circulate through a global maze in which ownership is obscured while profits, assets, and taxes are lost. In a groundbreaking report which uses World Bank and IMF data to estimate the quantity and patterns of illicit financial flows coming out of developing countries, the Global Financial Integrity (GFI,2010) documented Nigeria as the leading source of illicit financial outflow from sub-Sahara Africa during the years 2000 to 2009. The report showed that developing countries lost USD 903 billion in illicit outflows in 2009. While this marks a significant decrease from the USD 1.55 trillion they lost in 2008, the global financial crisis accounts for the vast majority of the decrease, rather than improved governance or economic reforms (www.gfintegrity.org). According to that report, developing countries lost between USD 723 billion and USD 844 billion per annum on average through illicit flows over the decade ending 2009. (www.controlcapital.net)

Despite the onset of the global financial crisis in the same period, illicit flows increased in current dollar terms by $15.19 \%$ per annum from USD 386 billion at the start of the decade to USD 903 billion in 2009 (www.controlcapital.net). Adjusted for inflation, illicit financial flows still grew by $10.6 \%$ making the developing world lose USD 859 billion in illicit outflows in 2010 , an increase of $11 \%$ over 2009 . The report also revealed that illicit financial flows have increased in every region of developing countries. The real growth of illicit flows by regions over the period of study is shown as follows: Africa 23.8 percent, the Middle East and North Africa (MENA) 26.3 percent, developing Europe 3.6 percent, Asia 7.8 percent, and Western Hemisphere 2.7 percent. The group also ranked Nigeria as the 7th among the top 10 countries with the highest measured cumulative illicit financial outflows between 2001 and 2010 with the list showing China as first with $\$ 2.74$ trillion followed by Mexico with $\$ 476$ billion, others are Malaysia: $\$ 285$ billion, Saudi Arabia: $\$ 210$ billion, Russia: $\$ 152$ billion, Philippines: $\$ 138$ billion, Nigeria: $\$ 129$ billion, India: $\$ 123$ billion, Indonesia: $\$ 109$ billion, United Arab Emirates: $\$ 107$ billion (www.africanoutlookonline.com).

Global Financial Integrity (2013) assert that the drivers and trends of the illicit flows are seen in Trade mispricing which was found to account for an average of 80 percent of cumulative illicit flows from developing countries over the period of 2001-2010 and which is also the major channel for the transfer of illicit capital from China and Mexico. China continued to lead the world in illicit outflows, losing $\$ 420.4$ billion in 2010 as bribery, kickbacks, and the proceeds of corruption continued to be the primary driver of illicit financial flows from the Middle East and North Africa, while trade mispricing was the primary driver of illicit financial flows in the other regions (iff.gfintegrity.org). However, it was further reported that Qatar, Kuwait, Venezuela, and Poland were all displaced from the top-10 illicit financial flow ranking, and were replaced by the significantly poorer countries like Philippines, India, Indonesia, and Nigeria (www.africanonline.com).

The vehicle for sustainable development is the mobilization and proper utilization of domestic resources. In development parlance, 'financing for development' is about increasing resources while 'good governance' is about deploying them to meet development needs. However, illicit financial flow phenomenon has marred the growth and development of nations where they occur, especially the developing countries to which Nigeria belongs. In practice, illicit financial flows range from something as simple as a private individual transfer of funds into private accounts abroad without having paid taxes, to highly complex schemes involving criminal networks that set up multi-layered multi-jurisdictional structures to hide ownership. The causes of illicit financial flows over the years have been traced to weak financial management systems, political and macroeconomic instability. GFI (2010) opines that the massive flow of illicit money out of Africa is facilitated by a global shadow financial system comprising tax 
havens, secrecy jurisdictions, disguised corporations, anonymous trust accounts, fake foundations, trade mispricing, and money laundering techniques. The impact of these structures and the funds it shifts out of Africa is staggering. It drains foreign reserves, heightens inflation, reduces tax collection, cancels investment, and undermines free trade. It has its greatest impact on those at the bottom of the income scales in their countries, removing resources that could otherwise be used for poverty alleviation and economic growth.

Gamuchirai (2014) reviewing the report of United Nations Economic Commission for Africa (UNECA), an Ethiopian-based UN agency whose mandate is to foster intra-regional integration and promote Africa's development, classifies illicit financial flows in the following broad categories:

i. Proceeds of corruption: This is described as misappropriated public fund usually transferred and invested illegally in foreign banks by senior public officials with little or none of the illgotten wealth invested in local banks in order to avoid detection by the authorities.

ii. Trade mispricing: This is a popular way of transferring illicit funds abroad. It is mostly related to changes in volumes and value of the trade. This form of illicit financial flows is practised mainly by multinational corporations due to their size, presence and influence in some countries. Multinational corporations operating in countries with both high and low tax rates. Their multi-country presence enables them to carry out inter-subsidiary transfers between countries, which facilitate illicit transfers of funds abroad. According to UNECA, illicit financial flows from Africa measured through trade mispricing are highly concentrated in a few sectors, notably the extractive and mining industries. A report by UNECA highlights that in 2000-2009, $56 \%$ of the illicit financial flows from Africa arose from mispricing and smuggling of oil, precious metals and minerals, ores, copper, iron and steel.

iii. Revenues from illegal resource exploitation: Criminal activities have long been linked to illicit financial flows through cross-border smuggling and trafficking. This has become of concern to security agencies across the globe and in Africa. Growth in international commerce and transport coupled with weak enforcement capacity and corruption has made African countries a conduit through which illegally-extracted commodities are exported abroad illegally. An example of the illegal resource exploitation that promotes illicit financial flows in Africa is the illegal trade in wildlife and wildlife products. The United Nations Office on Drugs and Crime (UNODC) estimates that in 2011 between 5,600 and 15,400 elephants were killed in East Africa, translating to between 56 and 154 metric tons of ivory destined for Asian markets. The illegally-harvested ivory was estimated to have generated US\$ 31.5 million worth of illicit funds.

iv. Tax evasion: Transfer pricing is usually used to evade tax. Most multinational corporations seek to maximize profits artificially through maximizing expenses in high tax jurisdictions and maximizing revenue/income in low tax jurisdictions. Thus, because transfer pricing enables corporations to minimize tax payments illegally and transfer the funds abroad, this constitutes illicit financial flows. According to Global Financial Integrity (2013), the proceeds of commercial tax evasion perpetrated through trade mispricing account for an average of $54.7 \%$ of cumulative illicit flows from developing countries.

\subsection{Trend Analysis of Illicit Financial Flows from Nigeria}

The scale and regional composition of IFFs out of developing countries with particular reference to Nigeria is a matter of controversy. In Organization for Economic Cooperation and Development (OECD), there is a consensus that these flows not only surpass official development assistance but even the sum of those aid flows and foreign direct investment (OECD, 2013). Worthy of note is the marked growth in IFFs in all developing regions to date, though at different rates. For the 2002-2011 period, GFI concludes that the Middle East and 
North Africa (MENA) region registered the fastest trend rate of growth in illicit outflows (31.5 percent per annum) followed by Africa (19.8 percent), developing Europe (13.6 percent), Asia (7.5 percent), and the Western Hemisphere (3.1 percent), (Kar and LeBlanc, 2013). Existing research shows that African countries have experienced massive outflows of illicit capital mainly to Western financial institutions. In a GFI report, it was shown that over a 39 year period between $1970-2008$, Africa lost an astonishing US\$854 billion in cumulative capital flight-enough to not only wipe out the region's total external debt outstanding of around US $\$ 250$ billion (at end-December, 2008) but potentially leave US\$600 billion for poverty alleviation and economic growth. Instead, cumulative illicit flows from the continent increased from about US $\$ 57$ billion in the decade of the 1970 s to US $\$ 437$ billion over the nine years 2000-2008 (www.aefjn.org).

Dev (2015) opines that the magnitude of illicit outflows from Africa with Nigeria at the forefront strongly suggests that the region can boost the effectiveness of the external aid and other transfers that it receives by curtailing the leakage of illicit capital. The continent should adopt a range of policy measures to counter this phenomenon that is sequenced and implemented in a manner best suited to the nature and sources of each country's illicit flows. Carefully designed measures to strengthen governance, transparency and regulatory oversight can significantly reduce the volume of illicit outflows. With the right reforms, Africa and indeed Nigeria is poised to see an increase in government revenue generation and effectively allowing additional resources to be devoted to poverty alleviation and improving the business climate for sustainable economic growth.

\subsection{How illicit Financial Flows Hampers Economic Growth and Development}

Economic growth and development are key policy objectives of any government. The Nigerian economy is an open economy with international transactions constituting an important proportion of her aggregate economic activity. Consequently, the economic prospects and development of the country, like many developing countries, rest solidly on her international interdependence. The term economic growth is described as the positive and sustained increase in aggregate goods and services produced in an economy within a given period. When measured with the population of a given country, economic growth can be stated in terms of per capita income such that the aggregate production of goods and services in a given year is divided by the population of the country in the given period. Economic growth can also be stated in nominal or in real terms. Hence, when the increase in the aggregate level of goods and services is deflated by the rate of inflation, we have the real economic growth, otherwise when measured without deflating; it is called nominal economic growth.

Chisman (1984) sees development as a process of societal advancement, where improvement in the well-being of people is generated through a strong partnership between all sectors, corporate bodies and other groups in the society. Development is not only an economic exercise but also involves both socio-economic and political issues and pervades all aspect of societal life. Naomi (1995) believes that development is usually taken to involve not only economic growth but also the notion of equitable distribution, provision of health care, education, housing and other essential services all with a view to improving the individual and collective quality of life. Considering these various views, development encompasses social, economic, cultural and political development.

The direct economic impacts of illicit financial flows on developing countries cannot be precisely quantified. It may, however, be considered not only as negative but also of grave consequence. These outflows pose serious concern, as evident by inadequate growth, high levels of poverty, resource needs and the changing global landscape of official development assistance. There is broad consensus in the extant literature that IFFs deprive the affected countries of appreciable amounts of investment funds, which could otherwise spur economic growth and usefully complement foreign loans and aid payments in funding the public sector. Global Financial Integrity carried out a joint study with the African Development Bank and found that Africa 
was a net creditor to the world to the tune of up to $\$ 1.4$ trillion over the period from 1980 through 2009, with the most conservative estimate of the capital loss being around $\$ 600$ billion (Saheed and Ayodeji, 2012). Thus, despite the inflow of international aid into every region of Sub-Saharan Africa, outflows of illicit capital continue to result in a net loss of resources that overwhelms any positive economic effects of recorded capital inflows. Recognizing the particularly damaging effects of illicit financial flows on developing countries, leaders meeting at the Fourth High-Level Forum on Aid Effectiveness in Busan in 2011 agreed to" accelerate individual efforts to combat illicit financial flows by strengthening anti-money laundering measures, addressing tax evasion, and strengthening national and international policies, legal frameworks and institutional arrangements for the tracing, freezing and recovery of illegal assets. This includes ensuring enactment and implementation of laws and practices that facilitate effective international co-operation" (OECD, 2011a).

Combating illicit financial flows is a shared agenda, requiring action by both developed and developing countries. Illicit flows are often a symptom of a deeper governance failure and just one element of a wider set of governance challenges faced by many countries. High levels of corruption combined with weak institutions - and sometimes illegitimate regimes - are drivers for such outflows. Ultimately, the fight against illicit flows from the developing world must focus on building responsive, effective institutions which deliver services to their population. This will encourage citizens and companies to engage in legal activities, report their earnings and pay their taxes and dues in accordance with national laws.

\subsection{Others' view on IFFs, Economic Growth and Development}

There has not been much study regarding illicit financial flow and its impact in Nigeria. Most studies carried out have looked at Africa as a whole and came up with the following. Nkurunziza (2013) investigated illicit Financial Flows as a constraint on poverty reduction in Africa, from his analysis he concluded that if Africa is to successfully fight against its high level of poverty, it will need to mobilize more resources to invest in poverty-reducing programs. He was of the opinion that to fight this ugly trend African leaders need a strong political will to move forward and having known the amount that has left this continent over the years, it will be important to find ways of attracting them back.

Quentin and Alessandra (2011) examined corruption and illicit financial flows; they said that IFF is clouded by lack of terminological clarity, which obstructs the effective policy debate emerging in response to the financial crises, as the accepted wisdom of the deregulated global financial market. They assert that illicit financial flow is intimately linked to large-scale corruption and the acknowledgement of this is important in order to clarify the extent and ways in which corruption may be tackled via policies thereby stopping illicit flows. Finally, policy should go beyond anti-money laundering policies and embrace more fully other polices to tackle illicit funds, but also more decisive effort by rich countries that shelter secrecy havens or the proceeds of grand corruptions.

AU/ECA Panel 2011 did a work on illicit financial flows from Africa. They examined the nature, magnitude and developmental challenges of IFFs from Africa, based on disparities in national income accounts and trade date (trade mispricing). They also explored the extent to which financial secrecy among Africa countries had heightened the risk of IFFS. They used the World Bank Residual method, and International Monitory Fund (IMF) Direction of Trade Statistics (DOTS) based Trade mispricing method. Despite the significant variations, it was concluded that IFFs from the continent have been increasing over time and oil exporting countries tend to top the list of African net creditors to the world.

Dev and Devron (2008) conducted an investigation of illicit financial flow from Africa Hidden resource for development over a period of 39 years. The paper analyzed and used the World Bank Misinvoicing model to estimate the volume of flows from African countries and found that illicit flows from Africa grew at an average of $11.9 \%$ per annum real terms over the 39 years 
period, that sub-Saharan Africa registered the highest growth rate in over 30 years, they also analyzed trends in illicit flows in relation to GDP. The paper finds that the ratio for 2000-2008 takes shape dip because of much faster rate of growth during this period. (africannetresources.gfintegrity.org)

Similarly, Dev and Freitas (2011) empirically examined the amount of illicit financial flows from developing countries over the decade ending 2009. The study provided estimates of illicit financial flows (IFFs) from developing countries over the decade 2000-2009 based on the balance of payment (BOP), bilateral trade and external debt data reported by member countries. They used the residual model approach in doing the work. Their findings are that in 2009 IFFs from developing countries led by the top ten exporters of illicit capital, most of which are in Asia and the Middle East and North Africa region have declined by $41 \%$ over the last year. They also found out that this was due to global economic crises which tended to reduce the source of funds (New external loans and net foreign direct investments).

Ndikumana (2013) in an effort to establish the extent to which the investment-inhibiting effect of IFFs impact growth used data from a number of African developing countries to conduct an econometric simulation. The central question of the study is how much additional growth the affected countries might have achieved without illicit financial outflows. The findings are of course plagued by a number of uncertainties, however, the trend is impressive. Ndikumana concludes that the thirty-nine countries studied over the period from 2000 to 2010 might have been able to achieve on average 3 percent more economic growth had been a radical stop to all IFFs. In oil-exporting countries, which are especially prone to illicit financial outflows, that additional growth might even have been 3.9 percent.

\section{Research Methodology}

The data for this study were mainly secondary and sourced from the global financial integrity website and CBN statistical bulletins. In consideration of the specified variables, they were subjected to some test to ensure that adequate allowance was made for the dynamic relationship between the variables regarding stationary and cointegration. Unit root test was carried out to test for the stationary of the time series data using the Augmented Dickey-Fuller (ADF) test. Johansen Co-integration approach was adopted to test the long run relationship between the variables.

Model 1:

GDP $=f(I F F)$

Thus;

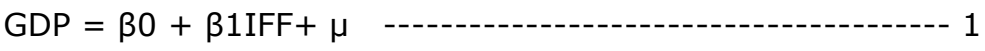

Where:

GDP $=$ Gross Domestic Product (Economic Growth)

IFF = Illicit Financial Flows

$\mu=$ Stochastic error term

Model 2

$\mathrm{PCI}=f(\mathrm{IFF})$

$\mathrm{PCI}=\beta 0+\beta 1 \mathrm{IFF}+\mu$

Where:

PCI $=$ Per Capital Income (Economic Development)

IFF $=$ Illicit Financial Flows

$\mu=$ Stochastic error term 


\section{Data Analysis and Interpretation}

Table 1: Unit Root Estimates: Augmented Dickey-Fuller (ADF) Trend and Intercept (Series at $2^{\text {nd }}$ difference)

\begin{tabular}{|c|c|c|c|c|c|c|}
\hline Series & $\begin{array}{c}\text { ADF test } \\
\text { Stat. } 1 \%\end{array}$ & $\begin{array}{c}\text { Cri. Value } \\
5 \%\end{array}$ & Value 10\% & Cri. Value & Order & Remark \\
\hline GDP_1 & -7.130979 & -4.273277 & -3.557759 & -3.212361 & $2(1)$ & Stationary \\
\hline GDP_P_C & -6.780465 & -4.273277 & -3.557759 & -3.212361 & $2(1)$ & Stationary \\
\hline IFF & -5.630858 & -4.273277 & -3.557759 & -3.212361 & $2(1)$ & Stationary \\
\hline
\end{tabular}

Source: Authors E-views Computation

The Augmented Dickey-Fuller (ADF) was employed to test for the stationarity or the existence of units roots in the variables. It is common to test the stability of time series data in economic analysis before the main estimation. Most economic variables are not stationary at level hence they have to be differenced (Gujarati, 2003). Considering the ADF test statistics at $1 \%, 5 \%$ and $10 \%$ critical values, it is observed that the test statistics are greater than the critical values. Thus, the series is said to be integrated at the 2 nd difference. The implication of this is that the variables are stationary at that level hence there is no evidence of unit root tested with the trend and intercept for the time series data employed for this study. The linear combination of the series integrated at the same order is safely inferred as co-integrated.

\section{(b) Analysis of Co-Integration Test for hypothesis 1}

\section{With GDP as the dependent variable}

Table 2: Unrestricted Cointegration Rank Test (Trace)

\begin{tabular}{|l|l|l|l|l|}
\hline $\begin{array}{l}\text { Hypothesize No of } \\
\text { CE(s) }\end{array}$ & Eigen Value & $\begin{array}{l}\text { Trace } \\
\text { Statistics } \\
0.05\end{array}$ & $\begin{array}{l}\text { Critical } \\
\text { Value }\end{array}$ & $\begin{array}{l}\text { Probabili } \\
\text { ty }\end{array}$ \\
\hline None $*$ & 0.574172 & 48.13573 & 15.49471 & 0.0000 \\
\hline At most $1^{*}$ & 0.453892 & 19.96298 & 3.841466 & 0.0000 \\
\hline
\end{tabular}

Trace test indicates 2 cointegratingeqn(s) at the 0.05 level

* denotes rejection of the hypothesis at the 0.05 level

**MacKinnon-Haug-Michelis (1999) p-values

Table 3: Unrestricted Co integration Rank Test (Maximum Eigen value)

\begin{tabular}{|l|l|l|l|l|}
\hline $\begin{array}{l}\text { Hypothesize No of } \\
\text { CE(s) }\end{array}$ & Eigen Value & $\begin{array}{l}\text { Trace } \\
\text { Statistics } \\
0.05\end{array}$ & $\begin{array}{l}\text { Critical } \\
\text { Value }\end{array}$ & Probability \\
\hline None $*$ & 0.574172 & 28.17275 & 14.26460 & 0.0002 \\
\hline At most $1^{*}$ & 0.453892 & 19.96298 & 3.841466 & 0.0000 \\
\hline
\end{tabular}

Max-eigenvalue test indicates 2 cointegrating eqn(s) at the 0.05 level

$*$ denotes rejection of the hypothesis at the 0.05 level

**MacKinnon-Haug-Michelis (1999) p-values

(b) Analysis of Co-integration Test for hypothesis 2

With GDP per capita as the dependent variable 
Table 4: Unrestricted Cointegration Rank Test (Trace)

\begin{tabular}{|l|l|l|l|l|}
\hline $\begin{array}{l}\text { Hypothesize No } \\
\text { of CE(s) }\end{array}$ & Eigen Value & $\begin{array}{l}\text { Trace } \\
\text { Statistics } \\
0.05\end{array}$ & $\begin{array}{l}\text { Critical } \\
\text { Value }\end{array}$ & Probability \\
\hline None $*$ & 0.397789 & 16.89510 & 15.49471 & 0.0306 \\
\hline At most $1^{*}$ & 0.004814 & 0.159260 & 3.841466 & 0.6898 \\
\hline
\end{tabular}

Trace test indicates 1 cointegrating eqn(s) at the 0.05 level

* denotes rejection of the hypothesis at the 0.05 level

**MacKinnon-Haug-Michelis (1999) p-values

Table 5: Unrestricted Cointegration Rank Test (Maximum Eigen value)

\begin{tabular}{|l|l|l|l|l|}
\hline $\begin{array}{l}\text { Hypothesize No of } \\
\mathrm{CE}(\mathrm{s})\end{array}$ & Eigen Value & $\begin{array}{l}\text { Trace } \\
\text { Statistics } \\
0.05\end{array}$ & $\begin{array}{l}\text { Critical } \\
\text { Value }\end{array}$ & Probability \\
\hline None $*$ & 0.397789 & 16.73584 & 14.26460 & 0.0199 \\
\hline At most $1^{*}$ & 0.004814 & 0.159260 & 3.841466 & 0.6898 \\
\hline
\end{tabular}

Max-eigenvalue test indicates 1 cointegratingeqn(s) at the 0.05 level

* denotes rejection of the hypothesis at the 0.05 level

**MacKinnon-Haug-Michelis (1999) p-values

The unrestricted Johansen Co-integration test results indicate the existence of a stable and long-run relationship between the variables. From the test, it was found that the variables with trend and intercept indicated that time series data test are integrated of the same order. The linear combination of series integrated of the same order is therefore said to be co-integrated. The level of their integration indicates the number of time the series has to be differenced before stationary is induced. This implies that the variables have a long-run relationship and are likely to have the impact on one another. Also, this relationship is further buttressed by the Adjusted R2 of $56 \%$ indicating that to large extent illicit financial flows affects the growth and development of Nigeria. The remaining $44 \%$ are accounted for by the error term or other variables not captured in this study.

\section{Conclusion and Recommendations}

The mobilization and proper utilization of domestic resources lie at the heart of the process of sustainable development and growth. Illicit financial flow undermines both. Suffice to say that this menace remains one of the major economic problems confronting Nigeria and indeed Africa as a whole as evidenced by the findings of this study. The resource drain on Nigeria and countries in the Sub-Saharan Africa over the past thirty years is almost equivalent to Africa's current GDP. This represents a major drag on African development and dwarfs much of the effort that donor countries undertake to boost the continent's struggling economies. This poses a threat not only to Nigeria but Africa as a whole. Based on the above empirical findings we, therefore, conclude that illicit financial flows have a significant impact on economic growth and development of Nigeria given this the following recommendations are made:

- The government of Nigeria and indeed other sub-Saharan Africa must partner with governments of developed nations to monitor the movement of funds out of Nigeria into tax havens and secrecy jurisdictions and ensure that the culprits are brought to book.

- Nigeria must develop customs capacity in order to fight the massive outflows of capital through illicit practices. Adequate training and retraining must be given to meet current global practice.

- Government and regulatory bodies must ensure that banks and tax haven regularly report to the Bank of the International Settlements (BIS) detailed deposits by sector, maturity, and country of residence of deposit holders. 
- The government should address the problem of shell companies by requiring that all corporations, foundations, and trusts confirm beneficial ownership information in all banking and securities accounts.

- The government must address capacity issues and fight corruption domestically within and outside tax authorities.

- Pursue automatic cross-border exchange of tax information on personal and business accounts, ideally on a multilateral basis.

\section{References}

- Baker, R.W. (2005). Capitalism Achikes: Dirty money and how to renew the free-Market system. Hoboken wiley and sons.

- Beine, M.F, Docquier\&Rapoport, H., (2001). Brain drain and economic growth; theory and evidence.Journal of Development Economics 64(1): 275-289. Crossref

- Dev, K. (2015). Illicit Financial Flows from Africa: Causes, Consequences, and Curtailment Georgetown Journal of International affairs

- Global Financial Integrity (2013).'Illicit financial flows and the problem of net resource transfers from Africa: 1980-2009, http://www.gfintegrity.org

- Global Financial Integrity. (2010). Illicit Financial Flows from Africa: Hidden Resource for Development. Washington, DC: Global Financial Integrity.

- Global Financial Integrity and African Development Bank (2013). Illicit Financial Flows and the Problem of Net Resource Transfers from Africa: 1980-2009. Report. May 2013. http://www.gfintegrity.org/storage/gfip/documents/reports/AfricaNetResources/gfi afdb i ffs and the problem of net resource transfers from africa 1980-2009-web.pdf

- Kar,D. \&Freitas, S. (2012) Illicit Financial Flows from developing countries

- 2001-2010. A December 2012 report from Global Financial Integrity

- Melvin D.A\&Folarin, G. S. (2014) Governance and Illicit Financial flows.

- Naomi, O. (1995) Towards an integrated view of Human rights. Hunger Tech Net 6(3) 6-7.

- Ndikumana L. (2013) Capital flight and tax Haven: Impact on investment and Growth in Africa, contribution to European Development Berlin 11-13 Dec.

- Peter Jansky,(2013) Illicit Financial Flow and2013 commitment to Development

- Centre for Global Development (CGD) Policy paper034. Dec 2013.

- Quentin, R. \& Alessandria, F.(2011). Corruption and Illicit Financial Flows- the limits and possibilities of current approaches.

- Reuter P.\&Truman, E (2004). Chasing Dirty Money. The Fight against Money Laundry Washington D C Institute for International Economies.

- RostowW.W.The Five stages of Growth Development and Underdevelopment:

- The Political Economy of Global Inequality 3rd edition pp123-131.Transaction Book

- UNECA. (2013). Economic Report on Africa 2013: Making the Most of Africa's Commodities: Industrializing for Growth, Jobs, and Economic Transformation. Addis Ababa, Ethiopia: UNECA.

- Kar, D. (2011). Illicit financial flows from the least developed countries: 1970-2008. New York: UNDP.

- Ndikumana, L., \& Boyce, J. K. (2011b). Capital flight from sub-Saharan African countries: linkages with external borrowing and policy options. International Review of Applied Economics, 25(2), 149-170. Crossref

- Ndikumana, L., \& Boyce, J. K. (2012). Capital flight from North African countries. PERI Research Report. Amherst, MA: Political Economy Research Institute.

- Nkurunziza, J. D. (2013). The potential effect of capital flight on the rate of poverty reduction in Africa. In I. Ajayi\& L. Ndikumana (Eds.), Capital Flight from Africa: Causes, Effects and Policy Issues. Oxford, UK: Oxford University Press

- Saheed, Z.S. \&Ayodeji, S. (2012) Impact of capital flight on exchange rate and economic growth in Nigeria. International Journal of Humanities and Social Sciences. 2(13), pp247255 
- http://www.africanoutlookonline.com/index.php/economy/6040-nigeria-is-7th-amongcountries-with-illicit-financial-flows-report Business, Economy, Money \& Investment News

- http://www.africaundisguised.com/newsportal/story/nigeria-leads-illicit-financial-outflowsub-sahara-africa-global-financial-integritys-report Nigeria Leads in Illicit Financial Outflow From Sub-Sahara Africa - Global Financial Integrity's Report

- Council for international development (2014) http://iffoadatabase.trustafrica.org/iff/Factsheet-14-Illicit-Financial-Flows-3.14.pdf

- http://www.controlcapital.net

- http://www.gfintegrity.org/wp-content/uploads/2014/05/gfi_africareport_web.pdf

- http://www.flarenetworks.org

- http://www.africannetresources.gfintegrity.org

\section{Appendix}

\begin{tabular}{|c|c|c|c|c|}
\hline \multicolumn{4}{|c|}{ Null Hypothesis: D(GDP_1,2) has a unit root } & \\
\hline \multicolumn{5}{|c|}{ Exogenous: Constant, Linear Trend } \\
\hline \multicolumn{5}{|c|}{ Lag Length: 1 (Automatic - based on SIC, maxlag =2) } \\
\hline & & & t-Statistic & Proh * \\
\hline & & & & \\
\hline \multicolumn{3}{|c|}{ Augmented Dickey-Fuller test statistic } & -7.130979 & 0.0000 \\
\hline \multirow[t]{3}{*}{ Test critical values: } & $1 \%$ level & & -4.273277 & \\
\hline & $5 \%$ level & & -3.557759 & \\
\hline & $10 \%$ level & & -3.212361 & \\
\hline \multicolumn{4}{|c|}{ *MacKinnon (1996) one-sided p-values. } & \\
\hline \multicolumn{4}{|c|}{ Augmented Dickey-Fuller Test Equation } & \\
\hline \multicolumn{4}{|c|}{ Dependent Variable: D(GDP_1,3) } & \\
\hline \multicolumn{3}{|c|}{ Method: Least Squares } & & \\
\hline \multicolumn{3}{|c|}{ Date: $07 / 10 / 17$ Time: 04:26 } & & \\
\hline \multicolumn{3}{|c|}{ Sample (adjusted): 19842015} & & \\
\hline \multicolumn{5}{|c|}{ Included observations: 32 after adjustments } \\
\hline Variable & Coefficient & Std. Error & t-Statistic & Prob. \\
\hline & & & & \\
\hline $\mathrm{D}\left(\mathrm{GDP} \_1(-1), 2\right)$ & -2.228504 & 0.312510 & -7.130979 & 0.0000 \\
\hline $\mathrm{D}\left(\mathrm{GDP} \_1(-1), 3\right)$ & 0.386460 & 0.174300 & 2.217216 & 0.0349 \\
\hline $\mathrm{C}$ & -1443.040 & 3862960. & -0.000374 & 0.9997 \\
\hline @TREND(1980) & 66.82071 & 179044.3 & 0.000373 & 0.9997 \\
\hline R-squared & 0.832990 & Mean de & endent var & -80.87500 \\
\hline Adjusted R-squared & 0.815096 & S.D. dep & ndent var & 21747482 \\
\hline S.E. of regression & 9351528. & Akaike in & o criterion & 35.05645 \\
\hline Sum squared resid & $2.45 \mathrm{E}+15$ & Schwarz & riterion & 35.23966 \\
\hline Log likelihood & -556.9031 & Hannan- & uinn criter. & 35.11718 \\
\hline F-statistic & 46.55141 & Durbin- & atson stat & 2.234030 \\
\hline Prob(F-statistic) & 0.000000 & & & \\
\hline
\end{tabular}




\begin{tabular}{|c|c|c|c|c|}
\hline \multicolumn{4}{|c|}{ Null Hypothesis: $\mathrm{D}(\mathrm{IFF}, 2)$ has a unit root } & \\
\hline \multicolumn{4}{|c|}{ Exogenous: Constant, Linear Trend } & \\
\hline \multicolumn{5}{|c|}{ Lag Length: 2 (Automatic - based on SIC, maxlag=2) } \\
\hline & & & t-Statistic & Prob.* \\
\hline \multicolumn{3}{|c|}{ Augmented Dickey-Fuller test statistic } & -5.630858 & 0.0000 \\
\hline \multirow[t]{3}{*}{ Test critical values: } & $1 \%$ level & & -4.273277 & \\
\hline & $5 \%$ level & & -3.557759 & \\
\hline & $10 \%$ level & & -3.212361 & \\
\hline \multicolumn{5}{|c|}{ *MacKinnon (1996) one-sided p-values. } \\
\hline \multicolumn{4}{|c|}{ Augmented Dickey-Fuller Test Equation } & \\
\hline \multicolumn{3}{|c|}{ Dependent Variable: $\mathrm{D}(\mathrm{IFF}, 3)$} & & \\
\hline \multicolumn{3}{|c|}{ Method: Least Squares } & & \\
\hline \multicolumn{3}{|c|}{ Date: $07 / 10 / 17$ Time: $04: 35$} & & \\
\hline \multicolumn{3}{|c|}{ Sample (adjusted): 19852015} & & \\
\hline \multicolumn{4}{|c|}{ Included observations: 31 after adjustments } & \\
\hline Variable & Coefficient & Std. Error & t-Statistic & Prob. \\
\hline $\mathrm{D}(\operatorname{IFF}(-1), 2)$ & -4.390246 & 0.503640 & -8.717036 & 0.0000 \\
\hline $\mathrm{D}(\operatorname{IFF}(-1), 3)$ & 2.463574 & 0.410465 & 6.001904 & 0.0000 \\
\hline $\mathrm{D}(\operatorname{IFF}(-2), 3)$ & 1.200094 & 0.242996 & 4.938747 & 0.0000 \\
\hline $\mathrm{C}$ & 1969.889 & 3107.732 & 0.633867 & 0.5317 \\
\hline @TREND(1980) & -123.0139 & 143.1514 & -0.859327 & 0.3980 \\
\hline R-squared & 0.869508 & \multicolumn{2}{|c|}{ Mean dependent var } & -735.2548 \\
\hline Adjusted R-squared & 0.849432 & \multicolumn{2}{|c|}{ S.D. dependent var } & 18038.67 \\
\hline S.E. of regression & 6999.556 & \multicolumn{2}{|c|}{ Akaike info criterion } & 20.69177 \\
\hline Sum squared resid & $1.27 \mathrm{E}+09$ & \multicolumn{2}{|c|}{ Schwarz criterion } & 20.92306 \\
\hline Log likelihood & -315.7225 & \multicolumn{2}{|c|}{ Hannan-Quinn criter. } & 20.76717 \\
\hline F-statistic & 43.31147 & \multicolumn{2}{|c|}{ Durbin-Watson stat } & 2.512031 \\
\hline Prob(F-statistic) & 0.000000 & & & \\
\hline
\end{tabular}




\begin{tabular}{|c|c|c|c|c|}
\hline \multicolumn{5}{|c|}{ Null Hypothesis: D(GDP_PER_CAPITA,2) has a unit root } \\
\hline \multicolumn{5}{|c|}{$\begin{array}{l}\text { Exogenous: Constant, Linear Trend } \\
\text { Lag Length: } 1 \text { (Automatic - based on SIC, maxlag }=2 \text { ) }\end{array}$} \\
\hline & t-Statistic & Prob.* \\
\hline \multicolumn{3}{|c|}{ Augmented Dickey-Fuller test statistic } & -6.780465 & 0.0000 \\
\hline \multirow[t]{3}{*}{ Test critical values: } & $1 \%$ level & & -4.273277 & \\
\hline & $5 \%$ level & & -3.557759 & \\
\hline & $10 \%$ level & & -3.212361 & \\
\hline \multicolumn{5}{|c|}{ *MacKinnon (1996) one-sided p-values. } \\
\hline \multicolumn{5}{|c|}{ Augmented Dickey-Fuller Test Equation } \\
\hline \multicolumn{4}{|c|}{ Dependent Variable: D(GDP_PER_CAPITA,3) } & \\
\hline \multicolumn{3}{|c|}{ Method: Least Squares } & & \\
\hline \multicolumn{3}{|c|}{ Date: $07 / 10 / 17$ Time: $04: 34$} & & \\
\hline \multicolumn{3}{|c|}{ Sample (adjusted): 19842015} & & \\
\hline \multicolumn{4}{|c|}{ Included observations: 32 after adjustments } & \\
\hline Variable & Coefficient & Std. Error & t-Statistic & Prob. \\
\hline $\begin{array}{c}\text { D(GDP_PER_CAPITA(- } \\
1), \overline{2})\end{array}$ & -2.267027 & 0.334347 & -6.780465 & 0.0000 \\
\hline $\begin{array}{l}\text { D(GDP_PER_CAPITA(- } \\
1), 3)\end{array}$ & 0.377028 & 0.183984 & 2.049243 & 0.0499 \\
\hline $\mathrm{C}$ & 110.4872 & 111.6461 & 0.989620 & 0.3308 \\
\hline @TREND(1980) & -5.471809 & 5.170889 & -1.058195 & 0.2990 \\
\hline R-squared & 0.840591 & Mean dep & endent var & -8.382812 \\
\hline Adjusted R-squared & 0.823511 & S.D. dep & ndent var & 641.9727 \\
\hline S.E. of regression & 269.6966 & Akaike in & o criterion & 14.14894 \\
\hline Sum squared resid & 2036615. & Schwarz & riterion & 14.33216 \\
\hline Log likelihood & -222.3830 & Hannan- & uinn criter. & 14.20967 \\
\hline F-statistic & 49.21611 & Durbin- $\mathrm{W}$ & atson stat & 2.013282 \\
\hline Prob(F-statistic) & 0.000000 & & & \\
\hline
\end{tabular}




\begin{tabular}{|c|c|c|c|c|}
\hline \multicolumn{5}{|c|}{ Date: $07 / 10 / 17$ Time: $04: 41$} \\
\hline \multicolumn{5}{|c|}{ Sample (adjusted): 19832015} \\
\hline \multicolumn{5}{|c|}{ Included observations: 33 after adjustments } \\
\hline \multicolumn{5}{|c|}{ Trend assumption: Linear deterministic trend } \\
\hline \multicolumn{5}{|c|}{\begin{tabular}{|l|l|} 
Series: GDP_1 IFF & \\
\end{tabular}} \\
\hline \multicolumn{5}{|c|}{ Lags interval (in first differences): 1 to 2} \\
\hline \multicolumn{5}{|c|}{ Unrestricted Co integration Rank Test (Trace) } \\
\hline Hvnothesized & & Trace & 005 & \\
\hline No. of $\mathrm{CE}(\mathrm{s})$ & Eigenvalue & Statistic & Critical Value & Prob.** \\
\hline & & & & \\
\hline None * & 0.574172 & 48.13573 & 15.49471 & 0.0000 \\
\hline At most $1 *$ & 0.453892 & 19.96298 & 3.841466 & 0.0000 \\
\hline \multicolumn{5}{|c|}{ Trace test indicates 2 cointegratingeqn(s) at the 0.05 level } \\
\hline \multicolumn{5}{|c|}{$*$ denotes rejection of the hypothesis at the 0.05 level } \\
\hline \multicolumn{5}{|c|}{ **MacKinnon-Haug-Michelis (1999) $\mathrm{p}$-values } \\
\hline & & & & \\
\hline \multicolumn{5}{|c|}{ Unrestricted Cointegration Rank Test (Maximum Eigenvalue) } \\
\hline & & & & \\
\hline Hypothesized & & Max-Eigen & 0.05 & \\
\hline No. of $\mathrm{CE}(\mathrm{s})$ & Eigenvalue & Statistic & Critical Value & Prob.** \\
\hline None * & 0.574172 & 28.17275 & 14.26460 & 0.0002 \\
\hline At most $1 *$ & 0.453892 & 19.96298 & 3.841466 & 0.0000 \\
\hline \multicolumn{5}{|c|}{ Max-eigenvalue test indicates 2 cointegratingeqn(s) at the 0.05 level } \\
\hline \multicolumn{5}{|c|}{$*$ denotes rejection of the hypothesis at the 0.05 level } \\
\hline \multicolumn{5}{|c|}{ **MacKinnon-Haug-Michelis (1999) $\mathrm{p}$-values } \\
\hline \multicolumn{5}{|c|}{ Unrestricted Cointegrating Coefficients (normalized by $b^{\prime *} \mathrm{~S} 11^{*} \mathrm{~b}=\mathrm{I}$ ): } \\
\hline & & & & \\
\hline GDP_1 & IFF & & & \\
\hline $1.03 \mathrm{E}-08$ & 0.000254 & & & \\
\hline $1.57 \mathrm{E}-07$ & -0.000210 & & & \\
\hline \multicolumn{5}{|c|}{ Unrestricted Adjustment Coefficients (alpha): } \\
\hline & & & & \\
\hline D(GDP_1) & -4274067. & 1311004. & & \\
\hline D(IFF) & 1488.104 & 2535.686 & & \\
\hline \multicolumn{2}{|c|}{1 Cointegrating Equation(s): } & $\begin{array}{l}\text { Log } \\
\text { likelihood }\end{array}$ & -869.7215 & \\
\hline \multicolumn{5}{|c|}{ Normalized cointegrating coefficients (standard error in parentheses) } \\
\hline GDP_1 & IFF & & 100 ill palentuाt & \\
\hline \multirow[t]{2}{*}{1.000000} & 24678.92 & & & \\
\hline & $(4302.58)$ & & & \\
\hline \multicolumn{5}{|c|}{ Adjustment coefficients (standard error in parentheses) } \\
\hline \multirow{2}{*}{$\mathrm{D}\left(\mathrm{GDP} \_1\right)$} & -0.044033 & & & \\
\hline & $(0.00825)$ & & & \\
\hline \multirow[t]{2}{*}{$\mathrm{D}(\mathrm{IFF})$} & $1.53 \mathrm{E}-05$ & & & \\
\hline & $(7.9 \mathrm{E}-06)$ & & & \\
\hline Date: $07 / 10 / 17$ & me: 04:51 & & & \\
\hline Sample (adjuste & 19832015 & & & \\
\hline Included observa & & & & \\
\hline
\end{tabular}




\begin{tabular}{|c|c|c|c|c|}
\hline \multicolumn{4}{|c|}{ Trend assumption: Linear deterministic trend } & \\
\hline \multicolumn{5}{|c|}{ Series: GDP_PER_CAPITA IFF } \\
\hline \multicolumn{5}{|c|}{ Lags interval (in first differences): 1 to 2} \\
\hline \multirow{2}{*}{\multicolumn{5}{|c|}{ Unrestricted Cointegration Rank Test (Trace) }} \\
\hline & & & & \\
\hline Hypothesized & & Trace & 0.05 & \\
\hline No. of $\mathrm{CE}(\mathrm{s})$ & Eigenvalue & Statistic & Critical Value & Prob.** \\
\hline None * & 0.397789 & 16.89510 & 15.49471 & 0.0306 \\
\hline At most 1 & 0.004814 & 0.159260 & 3.841466 & 0.6898 \\
\hline \multicolumn{5}{|c|}{ Trace test indicates 1 cointegratingeqn(s) at the 0.05 level } \\
\hline \multicolumn{5}{|c|}{$*$ denotes rejection of the hypothesis at the 0.05 level } \\
\hline \multirow{2}{*}{\multicolumn{5}{|c|}{$* *$ MacKinnon-Haug-Michelis (1999) p-values }} \\
\hline & & & & \\
\hline \multicolumn{5}{|c|}{ Unrestricted Cointegration Rank Test (Maximum Eigenvalue) } \\
\hline & & & & \\
\hline Hypothesized & & Max-Eigen & 0.05 & \\
\hline No. of CE(s) & Eigenvalue & Statistic & Critical Value & Prob.** \\
\hline None * & 0.397789 & 16.73584 & 14.26460 & 0.0199 \\
\hline At most 1 & 0.004814 & 0.159260 & 3.841466 & 0.6898 \\
\hline \multicolumn{5}{|c|}{ Max-eigenvalue test indicates 1 cointegratingeqn(s) at the 0.05 level } \\
\hline \multicolumn{5}{|c|}{$*$ denotes rejection of the hypothesis at the 0.05 level } \\
\hline \multicolumn{5}{|c|}{ **MacKinnon-Haug-Michelis (1999) p-values } \\
\hline & & & & \\
\hline \multicolumn{5}{|c|}{ Unrestricted Cointegrating Coefficients (normalized by $b^{\prime *} S 11 * b=I$ ): } \\
\hline GDP PER CAPIT & IFF & & & \\
\hline a & & & & \\
\hline-0.003408 & 0.000427 & & & \\
\hline-0.000231 & 0.000318 & & & \\
\hline \multirow{2}{*}{\multicolumn{5}{|c|}{ Unrestricted Adjustment Coefficients (alpha): }} \\
\hline & & & & \\
\hline D(GDP_PER_CA & 88.12900 & 11.85045 & & \\
\hline $\begin{array}{c}\text { PITA) } \\
\text { D(IFF) }\end{array}$ & & & & \\
\hline $\mathrm{D}(\mathrm{IFF})$ & -1919.845 & 274.1503 & & \\
\hline \multicolumn{2}{|c|}{1 Cointegrating Equation(s): } & $\begin{array}{c}\text { Log } \\
\text { likelihood }\end{array}$ & -543.4872 & \\
\hline \multicolumn{5}{|c|}{ Normalized cointegrating coefficients (standard error in parentheses) } \\
\hline $\begin{array}{c}\text { GDP_PER_CAPIT } \\
\text { A }\end{array}$ & IFF & & & \\
\hline \multirow[t]{2}{*}{1.000000} & -0.125274 & & & \\
\hline & $(0.02005)$ & & & \\
\hline \multicolumn{5}{|c|}{ Adjustment coefficients (standard error in parentheses) } \\
\hline $\begin{array}{c}\text { D(GDP_PER_CA } \\
\text { PITA) }\end{array}$ & -0.300330 & & & \\
\hline
\end{tabular}

